\title{
Diatoms of Modern Bottom Sediments in Siberian Arctic
}

\author{
O. V. Palagushkina ${ }^{a}$, L. B. Nazarova ${ }^{a, b}$, S. Wetterich ${ }^{b}$, and L. Schirrmeister ${ }^{b}$ \\ ${ }^{a}$ Kazan Federal (Volga Region) University, Institute of Management and Territorial Development, \\ Kremlevskaya ul. 18, Kazan, 420008 Russia \\ ${ }^{b}$ Alfred Wegener Institute of Polar and Marine Research, Telegrafenberg 43, Potsdam, 14473 Germany \\ e-mail: opalagushkina@mail.ru
}

\begin{abstract}
The investigation of the species composition and ecology of diatoms of modern bottom sediments in water bodies of arctic polygonal tundra in three subregions of North Yakutiya has been carried out. As a result, 161 taxons of diatoms were determined; the determinant role of the depth, conductivity, $\mathrm{pH}$ of the water, and geographic latitude in their distribution was confirmed, and two complexes of species with respect to the leading abiotic factors were distinguished. The diatoms of the first complex prefer shallow water bodies of high latitudes with neutral and slightly alkaline water and relatively high conductivity. The second complex is confined to the water bodies of lower latitudes with small conductivity, as well as neutral and slightly acidic water.
\end{abstract}

Keywords: Arctic water reservoirs, diatoms, bottom sediments, ecology, complexes

DOI: $10.1134 /$ S1995425512040105

Arctic regions are most sensitive to global climate change and Arctic waters are an excellent indicator of a current increase in air temperature on the planet [1]. Reservoirs of the polygonal tundra, the most characteristic types of aquatic ecosystems of the North Siberia, have a small depth (up to $3 \mathrm{~m}$ ) and a specific thermal and chemical mode, which makes them extremely susceptible to a climate change. Diatoms live in all surface waters of the earth; their siliceous cell walls are well preserved in a fossil state, which allows them to be used as biological indicators of changes in the environment (temperature, hydrochemical) [2,3].

The planktonic diatoms of modern freshwater reservoirs of Yakutiya have been studied since 1932 [4-17]. Fossilized diatoms sediments have been intensively studied for the last 15 years [18-25]; to date, diatoms of lake sediments of Central and Northern Yakutiya (sub- and lower arctic zones) are the most studied, whereas high-latitude lakes of this region (high-latitude Arctic zone at $71^{\circ} \mathrm{N}$ and above) are still poorly understood. There are only a few details about the New Siberian Islands waters, such as Bol'shoi Lyakhovskii [26-28] and Zhokhovskii [29], including diatoms of Quaternary period sediments.

The aim of our research is to study diatoms of modern bottom sediments of water bodies at the polygonal tundra of three subregions of Northern Yakutiya (Bol'shoi Lyakhovskii island, Oigosskii Yar coast, and the area near Tiksi) using diatom analysis, as well as to define a role of various physical, chemical, and geographical factors in a distribution of diatom taxa. This study is a continuation of a series of studies aimed at creating a database on the taxonomy and ecology of diatoms of Yakutiya [18-25], which is the basis for the future development of diatom models used for the quantitative paleoecological and paleoclimatic changes and reconstruction in northeastern Russia.

\section{MATERIAL AND METHODS}

In July through September 2007, samples of modern bottom sediments in permafrost zone reservoirs of the three subregions of Northern Yakutiya were collected, including 15 water bodies on the southern part of Bol'shoi Lyakhovskii island $\left(73^{\circ} \mathrm{N}, 141^{\circ} \mathrm{E}\right)$, 16 coastal water bodies at Oigosskii Yar (across the strait from the Bol'shoi Lyakhovskii Island, $72^{\circ} \mathrm{N}$, $143^{\circ} \mathrm{E}$ ), and three water bodies in the vicinity of Tiksi $\left(71^{\circ} \mathrm{N}, 128^{\circ} \mathrm{E}\right)$ (Fig. 1).

According to climatic demarcation, the investigated subregions belong to arctic and subarctic zones. The southern part of the Bol'shoi Lyakhovskii island belongs to the arctic climate zone and is characterized by a great difference in the duration of sunlight in summer and winter; the cold season lasts nine months and the frost-free period does not exceed 30-45 days. Average January temperatures vary from -32 to $-35^{\circ} \mathrm{C}$, average July temperatures vary from +6 to $+8^{\circ} \mathrm{C}$, and the average annual precipitation is less than $150 \mathrm{~mm}$. The Oigosskii Yar coast and Tiksi region belong to the subarctic climate zone. Here, the frostfree period is $50-70$ days, the average temperature in January is $-40^{\circ} \mathrm{C}$, average temperatures in July vary from +12 to $+14^{\circ} \mathrm{C}$, and the average annual precipitation is $200-300 \mathrm{~mm}[30,31]$. 


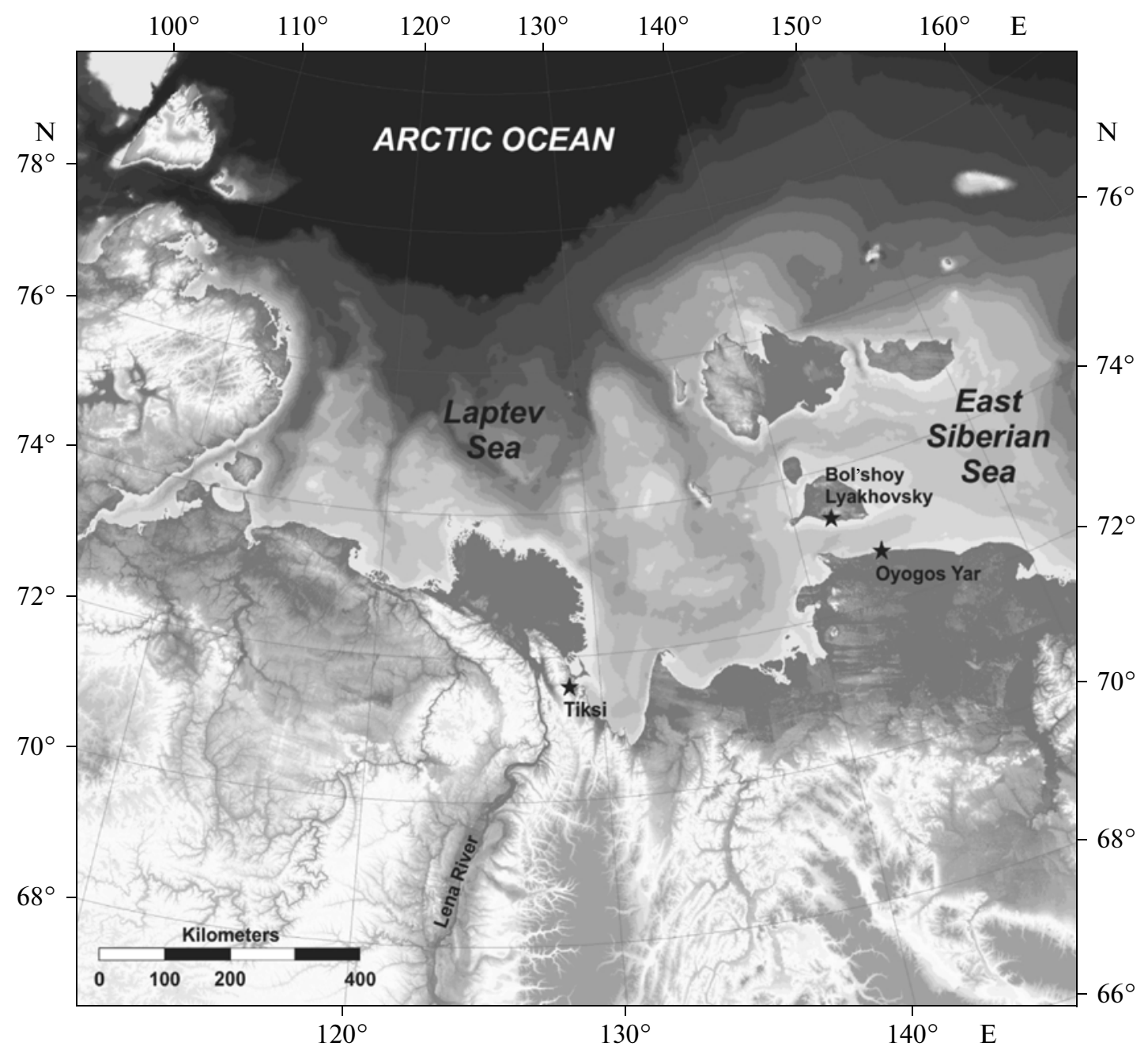

Fig. 1. Location of research areas. Map prepared by G. Grosse (University of Alaska, Fairbanks) using data from the International Bathymetric Chart of Arctic Ocean (IBCAO) and digital elevation model of the Earth (Globe DEM).

Water samples and surface sediment layer taken from each water body are represented by silt or sand material with a greater or lesser proportion of plant detritus.

Chemical analysis identified the type of water in most water bodies as hydrocarbonate-chloride with a predominance of magnesium cations. The typification of waters by subregions showed that, for reservoirs of the Bol'shoi Lyakhovskii island and the Oigosskii Yar coast, dominant anions are hydrocarbonate and chlorides and, for waters in the vicinity of Tiksi, the predominant type of water is hydrocarbonate calciummagnesium [32]. According to Alekin [33], the mineralization of the water of all studied water bodies is characterized as small and the water is very soft. The reaction $(\mathrm{pH})$ of water bodies of the Bol'shoi Lyakhovskii island is neutral or slightly alkaline and, for the lakes of the Oigosskii Yar coast and Tiksi, it is neutral or slightly acid. For water bodies in the vicinity of
Tiksi, the lowest values of conductivity and water hardness were recorded (Table 1).

The technical processing of sediment samples for diatom analysis was performed using the water bath method [34] in the laboratory of the Alfred Wegener Institute of Polar and Marine Research (Potsdam, Germany). To make permanent slides, we used a high refracting solution Naphrax. The species composition was determined using domestic and foreign data [35-39]. The calculation of the valves was performed in parallel transects, up to 500 in a sample, using a Zeiss Axioplan light microscope and immersion oil. The total number of valves was considered as $100 \%$. In the process, photos were taken of the most common species using a scanning electron microscope Ultra 55 Plus Zeiss in the Electron Microscopy Laboratory of the German Research Center of Geological Sciences, Helmholtz-Center Potsdam.

Ecological and geographic characteristics of diatoms included the habitat, salinity, $\mathrm{pH}$, geographic 


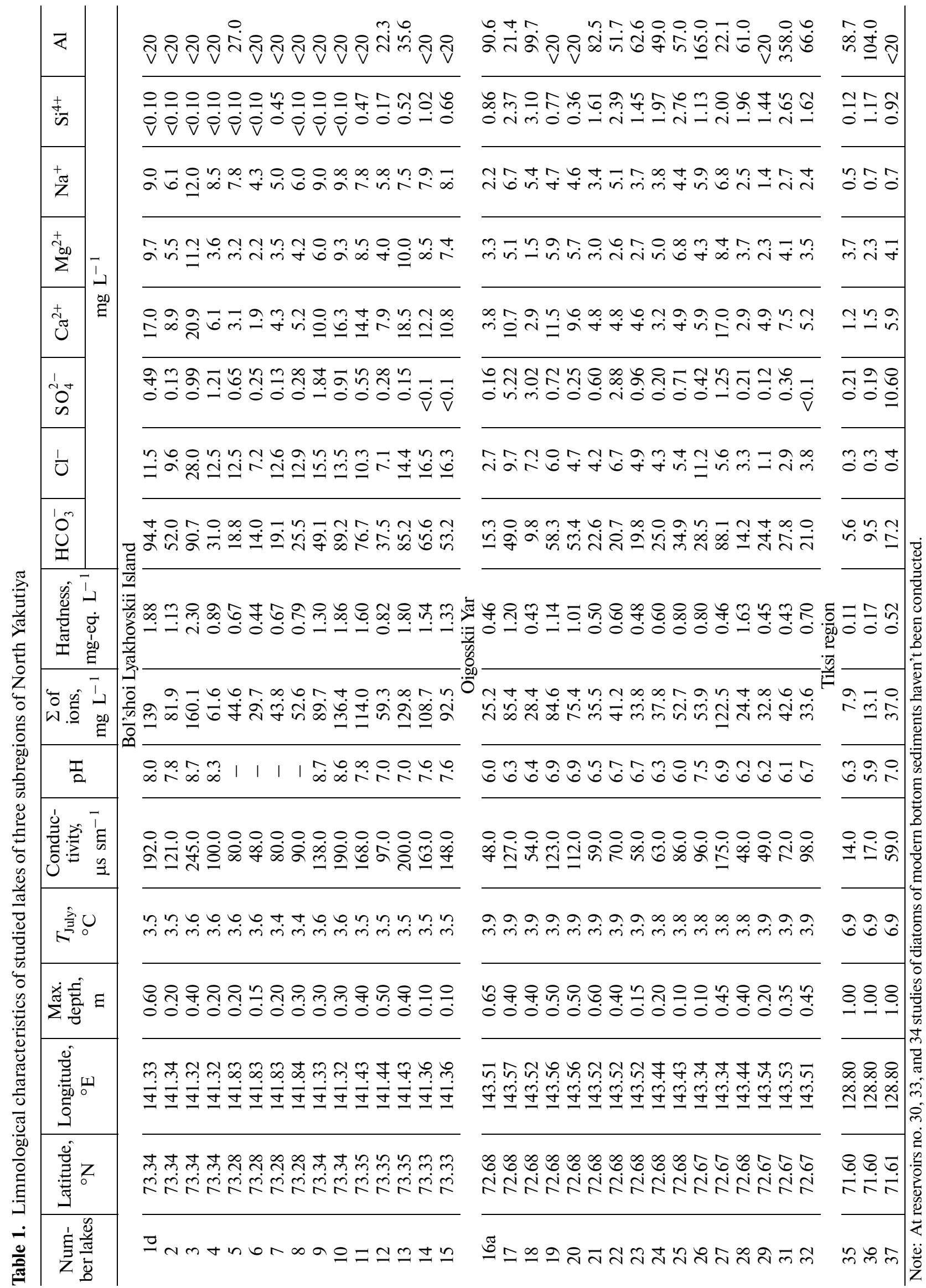


distribution, temperature confinement, and water velocity species [3, 40, 41]. The similarity of taxonomic composition of diatom communities was assessed by the Sörensen index [42].

For the statistical processing of the material, two software packages were used, i.e., Statistica 7 (factor analysis, based on the Spearman rank correlation $(r)$ at the permitted level for highlighting of $p<0.05$ ) and Canocco 4.5. To conduct a factor analysis, we used dominant diatoms (giving $10 \%$ or more of the total number of valves in a sample) and environmental parameters (Table 1). For charting with the dominant species of diatoms, the $\mathrm{C} 2$ version 1.3 program was used [43]. Statistical analysis was conducted in the program Canocco 4.5 largely in accordance with the methods of L.B. Nazarova et al. [44]. Diatoms found in at least one lake with a relative number of more than $5 \%$ were included in the analysis. According to this criterion, 46 of the 161 taxa found in lakes were submitted to the analysis. The method of indirect ordination and detrended correspondence analysis (DCA) was used to calculate the length of the overall environmental gradient veeded to evaluate the relationship (linear or unimodal) between environmental factors in the studied region and the distribution of diatoms [45]. DCA, i.e., data transformed by taking the square root, revealed that the gradient length of axis 1 is 3.46 standard deviation units, which determines the possibility of a unimodal ordination method, and the canonical correspondence analysis (CCA) [46].

In the statistical analysis (DCA) 19 environmental parameters were included, such as water temperature at a sampling time, Secchi disk transparency, the total phosphorus, nitrates, the total iron, etc. listed in Table 1. The data for these indicators are presented in the article of Wetterich et al. [32]. To achieve a normal distribution of concentrations of nitrates and aluminium, they were transformed using the logarithm. To test a multicollinearity of a complex of environmental variables variance inflation factor analysis (VIF) was made. Environmental parameters with the values of VIF of more than 20 were removed one by one, starting with the one that had the highest value of VIF, as long as the VIF values of all remaining factors were below 20. The minimum number of environmental parameters, which significantly explains the variations of diatom data, was then evaluated by the forward selection manual method.

\section{RESULTS AND DISCUSSION}

As a result of the studies of modern bottom sediments of 34 water bodies of North Yakutiya, 161 diatom taxa belonging to 25 genera, 13 families, 4 orders, and 2 classes were identified. This represents $32.5 \%$ of the total systematic list of diatoms sediments compiled for the 199 lakes in Yakutiya [25]. The most common species were Eunotia bilunaris (Ehr.) Mills., E. praerupta Ehr., E. tenella (Grun.) Hust., Tabellaria flocculosa (Roth) Kütz., Stauroneis phoenicenteron (Nitzsch.) Ehr., Cymbella silesiaca Bleisch in Rabenhorst, Stauroneis anceps Hust., Achnanthes minutissima Kütz., Gomphonema parvulum Kütz ., and Navicula pupula Kütz. (Fig. 2). Species that make up 5\% or more of the total number of valves in a sample and their distribution in the lakes of the three sub-regions of the North Yakutiya are shown in Fig. 3.

Most of the found diatoms are benthic organisms (73.3\% of the total number of taxa). Plankton-benthic forms comprise $15.5 \%$ and plankton species were the smallest group, $4.3 \%$.

In relation to the water salinity, most of the identified species are freshwater oligohalobes $(72 \%$ of the total number of species), of which a large part are indifferent $(53.4 \%)$, and a smaller part are halophiles $(9.3 \%)$ and halophobes (7.4\%). The presence of mesohalobes (1.9\%), i.e., Achnanthes flexella (Kütz.) Brun, Nitzschia levidensis (W. Smith) Grun. in van Heurck. (Bol'shoi Lyakhovskii), and Achnanthes hungarica Grun. (Oigosskii Yar), may indicate a genetic connection between lakes located on a low hypsometric level with the sea. The predominance of benthic that is indifferent with respect to the salinity species and the presence of mesohalobes were also noted in studies of L.A. Pestryakova [25].

Most of the noted species are indifferent to $\mathrm{pH}$ ( $26.1 \%$ of the total number of species). Inhabitants of waters with an alkaline reaction consist of $24.8 \%$, most of which are alkaliphiles (22.4\%), while some are alkalibionts (2.5\%); the proportion of acidophiles is $18.6 \%$.

Diatoms of bottom sediments of the arctic waters are presented mostly by cosmopolitan species (36\% of the total number of taxa), boreal species account for $11.2 \%$, and arctoalpines make up $9.9 \%$; holarctic and alpine-cosmopolitan species were also reported (1.86\% each) [3, 40, 41].

There is information on the temperature diapason for 31 species, 24 of which are inhabitants of moderate temperature conditions, while four prefer cold water and three are eurythermic [41].

There is only information about water velocity for 39 species of diatoms, species of still (17) and stillflowing waters (16) dominate, and species of flowing water are represented by five species; one aerophilic was also noted [41].

Ecological and geographic characteristics, as well as the proportions of diatom taxa in bottom sediments of the three subregions of the North Yakutiya, are shown in Table 2.

An analysis of the data shows the smallest number of diatom species in the lakes in the vicinity of Tiksi (63). The absence of mesohalobes and the highest percentage of halophobes, acidophiles, benthic and planktonic species, arctoalpines, and boreal and holarctic species, as well as prefering cold water species and species of still waters are characteristic. 

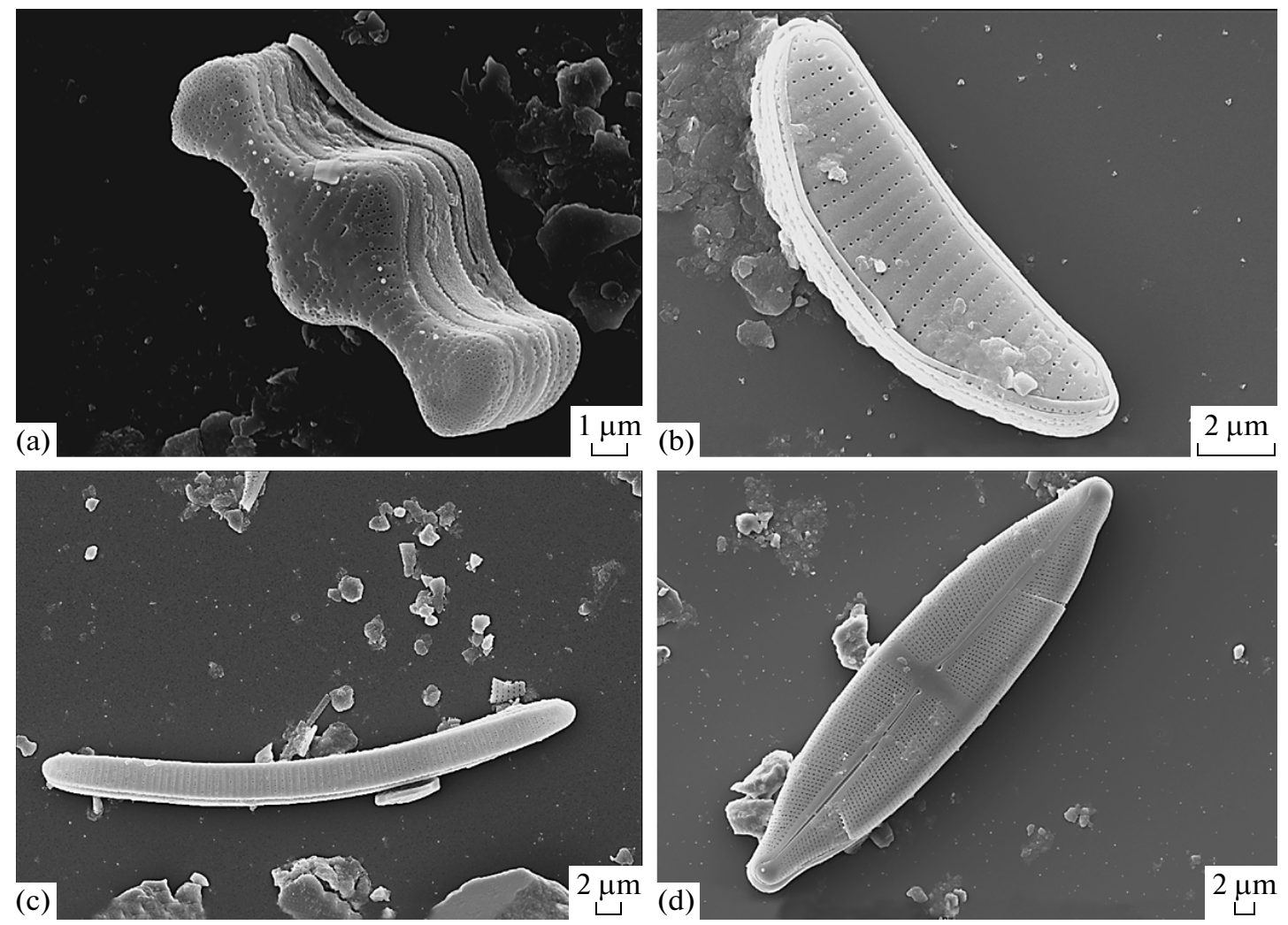

Fig. 2. (a) Tabellaria flocculosa, (b) Eunotia tenella, (c) Eunotia bilunaris, (d) Stauroneis phoenicenteron.

Considerable species richness was observed in water bodies of Bol'shoi Lyakhovskii island (87 taxa). They are characterized by the absence of planktonic species, which may be due to the short period of vegetation because of the high latitude and low air temperatures, as well as a shallowness $(0.1-0.6 \mathrm{~m})$. This group of lakes is also characterized by the highest proportion of halophiles, mesohalobes, and alkaliphiles and indifferent to $\mathrm{pH}$ species. Compared with other studied lakes, in reservoirs of the Bol'shoi Lyakhovskii island, the group of cosmopolitans were indifferent to temperature confinement; furthermore, flowing waters and aerophils were most represented.

The greatest number (109) of species of diatoms was found in bottom sediments of water bodies of Oigosskii Yar. In general, diatoms of reservoirs of the region are intermediate between diatoms of waters in the vicinity of Tiksi and the Bol'shoi Lyakhovskii island by their ecological characteristics. Of the characteristic features, the highest proportion of species were indifferent to salinity and water velocity, as well as the high proportion of alpine-cosmopolitans.

A comparison of the species composition of lakes in the three subregions showed the greatest similarity of diatoms of Bol'shoi Lyakhovskii island and the Oigosskii Yar coast (59.5\%). The similarity coefficient of diatoms of reservoirs of Oigosskii Yar coast and the vicinity of Tiksi was $41 \%$. The lowest similarity coefficient was observed between diatoms of the Bol'shoi Lyakhovskii Island and Tiksi (35\%).

CCA with 46 diatom taxa with a relative number of more than $5 \%$ in at least one lake (data on numbers of taxa were converted by taking the square root) and 19 environmental parameters showed that they were responsible for $33.8 \%$ of the variance of the taxonomic composition of diatoms and $52.5 \%$ of the interaction of species composition of diatoms with environment factors $(\lambda 1=0.327$ and $\lambda 2=0.160)$. Nine environmental parameters, i.e., latitude, longitude, $\mathrm{Ca}^{2+}$, conductivity, $T_{\text {July }}, \mathrm{Cl}^{-}, \mathrm{HCO}_{3}^{-}, \mathrm{Na}^{+}$, and $\mathrm{Mg}^{2+}$, had a VIF greater than 20 and, thus, strongly correlated to one another. One by one $T_{\text {July }}, \mathrm{HCO}_{3}^{-}$, and $\mathrm{Ca}^{2+}$ were removed from the analysis; then, the VIF of other environmental parameters fell below 20 . The remaining 16 environmental variables explained $32.0 \%$ of the variance in the species composition, which suggests that the removal of the three correlated variables do not actually affect the efficiency of the analysis.

The method of the manual forward selection in CCA (Monte Carlo test with 999 randomly drawn permutations) showed that, among the 16 most important variables that remain in the analysis, the $\mathrm{pH}$, depth, and conductivity form a set of statistically significant 


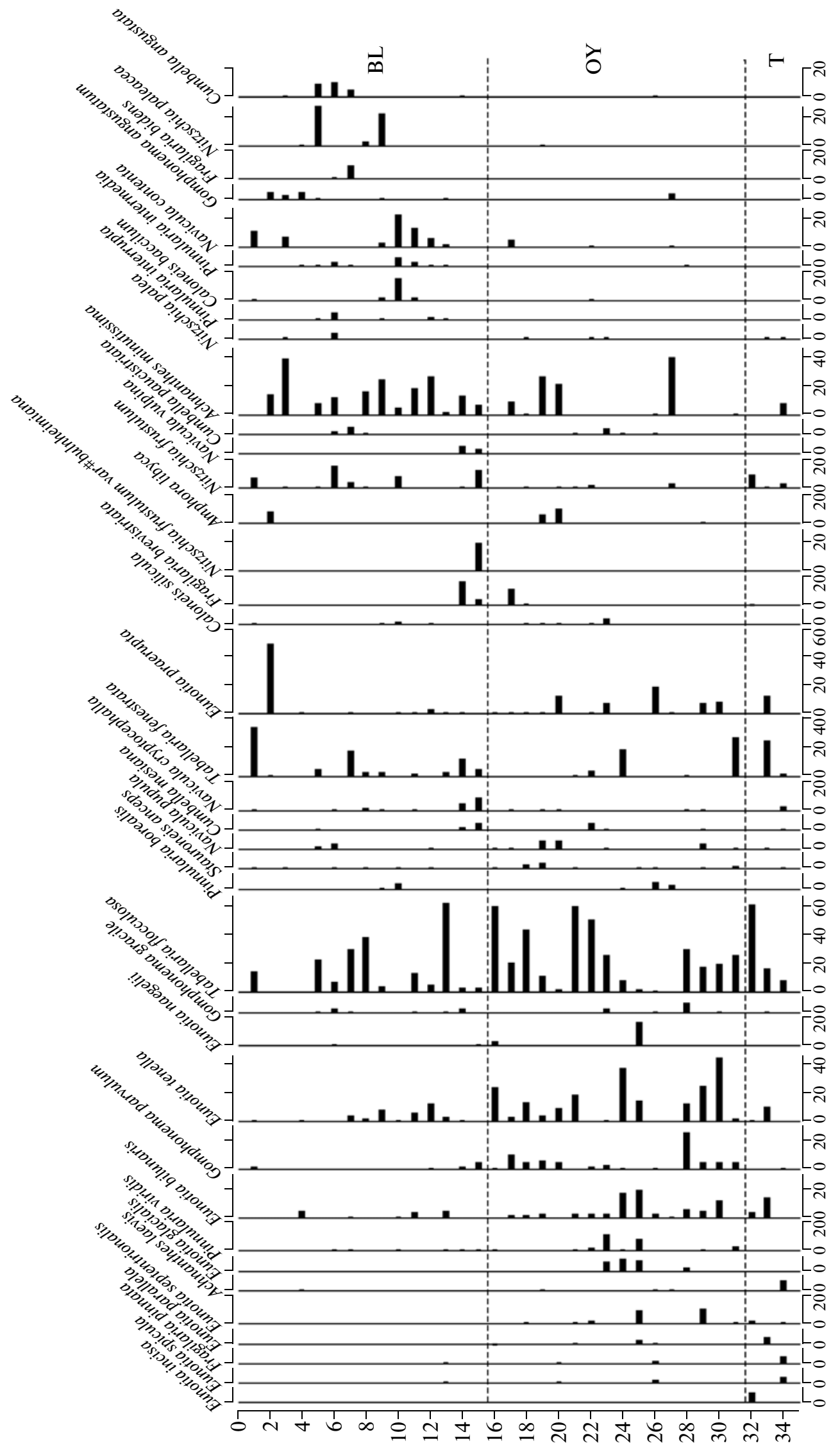

Fig. 3. Diagram of quantitative distribution of dominant diatom species of lakes of the three subregions of the North Yakutiya. (BL) Bol'shoi Lyakhovskii island, (OY) Oigosskii Yar coast, (T) Tiksi region. 
Table 2. Ecological and geographic characteristics and proportion of diatom taxa of different groups in bottom sediments of three subregions of North Yakutiya

\begin{tabular}{|c|c|c|c|}
\hline \multirow[b]{2}{*}{ Group of diatoms } & \multicolumn{3}{|c|}{ Proportions of total number of taxa, $\%$} \\
\hline & $\begin{array}{l}\text { Bol'shoi Lyakhovskii } \\
\text { island }\end{array}$ & Oigosskii Yar & Tiksi region \\
\hline \multicolumn{4}{|l|}{ By habitats: } \\
\hline benthic & 69 & 71.6 & 73 \\
\hline plankton-benthic & 23 & 18.3 & 19 \\
\hline plankton & 0 & 3.7 & 4.8 \\
\hline \multicolumn{4}{|l|}{$\begin{array}{l}\text { By mineralization: } \\
\text { oligohalobes: }\end{array}$} \\
\hline indifferents & 56.3 & 56.9 & 49.2 \\
\hline halophiles & 12.6 & 9.2 & 9.5 \\
\hline halophobes & 8 & 8.3 & 14.3 \\
\hline mesohalobes & 2.3 & 0.9 & 0 \\
\hline \multicolumn{4}{|l|}{ By relation to $\mathrm{pH}$ : } \\
\hline alkaliphiles & 33.3 & 26.6 & 17.5 \\
\hline alkalibionts & 1.1 & 2.8 & 1.6 \\
\hline indifferents & 31 & 29.4 & 25.4 \\
\hline acidophiles & 12.6 & 22.9 & 25.4 \\
\hline \multicolumn{4}{|l|}{ By geographic distribution: } \\
\hline boreal & 10.3 & 10.1 & 11.1 \\
\hline cosmopolitans & 58.6 & 52.3 & 49.2 \\
\hline arctoalpine & 8 & 11 & 14.3 \\
\hline alpine cosmopolitans & 1.2 & 2.8 & 0 \\
\hline holarctic & 1.2 & 0.9 & 1.6 \\
\hline \multicolumn{4}{|l|}{ By temperature confinement: } \\
\hline indifferents & 20.7 & 15.6 & 19 \\
\hline prefer cold waters & 3.5 & 2.8 & 6.3 \\
\hline eurythermic & 2.3 & 2.8 & 4.8 \\
\hline \multicolumn{4}{|l|}{ By water velocity: } \\
\hline still waters & 11.5 & 12 & 12.7 \\
\hline still or flowing waters (indifferents) & 11.5 & 12.8 & 3.2 \\
\hline flowing waters & 3.5 & 2.8 & 3.2 \\
\hline aerophilic & 1.1 & 0.9 & 0 \\
\hline
\end{tabular}

environmental variables $(p \leq 0.05)$, which better explains the variability in the number of diatom taxa in the studied lakes. The eigenvalues of axes 1 and 2 of the three most significant variables account for $\lambda 1=$ 0.282 and $\lambda 2=0.106$. In total, three canonical axes of CCA explain $22.0 \%$ variations in species composition of diatoms in the studied groups of lakes. The $\mathrm{pH}$ and conductivity were significantly positively correlated with the CCA axis 1, and the depth was positively and significantly correlated with the CCA axis 2 (Table 3 ).

With regard to the spatial arrangement of lakes relative to ordination axes 1 and 2, CCA has shown that the diatom communities of lakes of the three subre- gions of Yakutiya are different from each other, and in their formation different environmental factors are of primary importance. In the lakes in the vicinity of Tiksi (Fig. 4a), which positively correlated with ordination axis 2 , the depth of the water body played a dominant role. The weak positive correlation with the depth showed a plankton-benthic dominant species Tabellaria flocculosa $(r=0.37)$ (Fig. 4b).

The lakes of the Oigosskii Yar coast (Fig. 4a) are grouped on the left side of the ordination; i.e., they negatively correlate with the CCA axis 1 and have a mild positive or negative correlation with axis 2 . Diatoms of the lakes are largely benthic species, which 
Table 3. Correlation coefficients between environmental factors and CCA ordination axes

\begin{tabular}{l|r|r|r}
\hline \multirow{2}{*}{$\begin{array}{l}\text { Environmen- } \\
\text { tal factor }\end{array}$} & \multicolumn{3}{|c}{ Axis } \\
\cline { 2 - 4 } & 1 & 2 & \multicolumn{1}{c}{3} \\
\hline Depth & -0.0372 & 0.7850 & 0.3798 \\
pH & 0.8388 & -0.3434 & 0.1272 \\
Conductivity & 0.6786 & 0.0818 & -0.5430 \\
\hline
\end{tabular}

prefer slightly mineralised waters with low $\mathrm{pH}$ values, such as Eunotia septentrionalis Oest., E. tenella, E. bilunaris, E. praerupta, Tabellaria flocculosa, and Gomphonema parvulum (Fig. 4b).

Positive correlation of the lakes of the Bol'shoi Lyakhivskii Island with the CCA axis 1, as well as more pronounced, than among lakes of the Oigosskii Yar, dispersion along the axis 2 suggests that all three of important environmental factors play an important role in the formation of the diatom flora in the subregion (Fig. 4a). Diatoms are mostly benthic species developing at somewhat higher values of conductivity (and hence mineralization) with a neutral or slightly alkaline reaction of water, such as Navicula contenta Grun., Achnanthes minutissima, Caloneis baccilum (Grun.) Cleve, Nitzschia paleacea (Grun.) Grun., and Cymbella angustata (W. Sm.) Cl. (Fig. 4b).

A factor analysis revealed species that show a positive correlation with latitude, i.e., Navicula contenta $(r=0.54)$, Nitzschia paleacea $(r=0.41)$, Caloneis baccilum $(r=0.39)$, and Achnanthes minutissima $(r=$ $0.35)$. This is partly confirmed by the negative correla- tions with air temperature for species Cymbella angustata $(r=-0.41)$, Achnanthes minutissima $(r=$ $-0.39)$, and Navicula contenta $(r=-0.36)$. Species that negatively correlated with latitude were Eunotia septentrionalis Oest. $(r=-0.43)$, E. praerupta $(r=$ $-0.39)$, and Gomphonema parvulum $(r=-0.36)$, which allows one to classify them as a species of lower latitudes. Positive correlations with air temperature were also observed for species Eunotia septentrionalis $(r=0.5)$ and Gomphonema parvulum $(r=0.42)$, while a weaker correlation was observed for $E$. tenella $(r=$ $0.36)$.

The use of two statistical packages allows one to identify possible environmental factors that lead to the more complete formation of the species composition of diatoms in the waters of the three studied subregions.

\section{CONCLUSIONS}

The study showed that diatoms of modern bottom sediments of the North Yakutiya are numerous and various. Diatoms of the Bol'shoi Lyakhovskii island and the Oigosskii Yar coast are more similar in species composition, while diatoms of water bodies of the Bol'shoi Lyakhovskii island and the vicinity of Tiksi are less similar. The main environmental factors that affect the distribution of diatoms are the depth of the reservoir, $\mathrm{pH}$, and conductivity of water. The latitude that determines their air temperature also affects the distribution of algae in water bodies.

The statistical analysis allowed us to identify two sets of diatom species in relation to the leading abiotic (a)

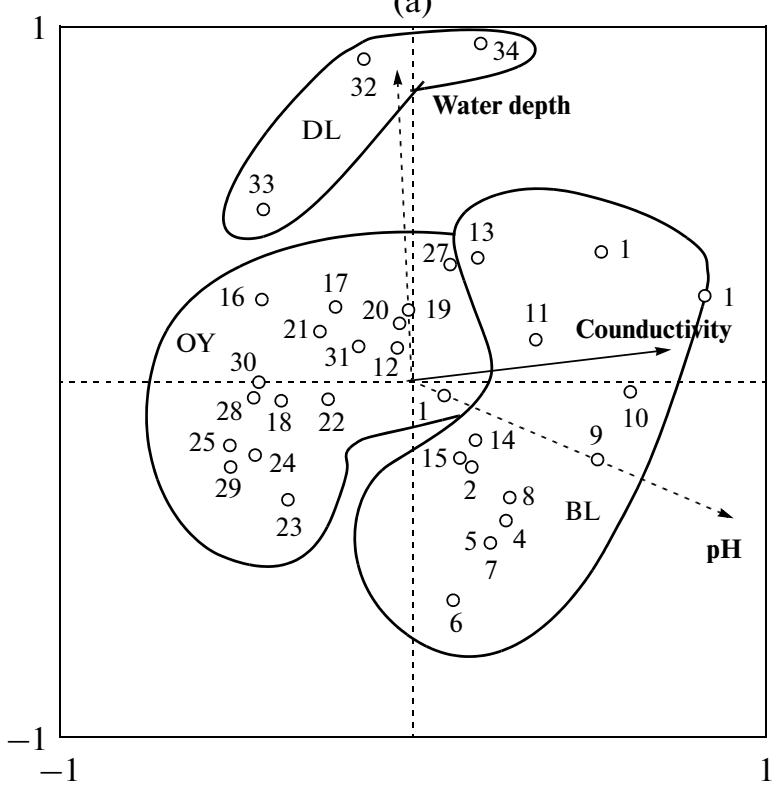

(b)

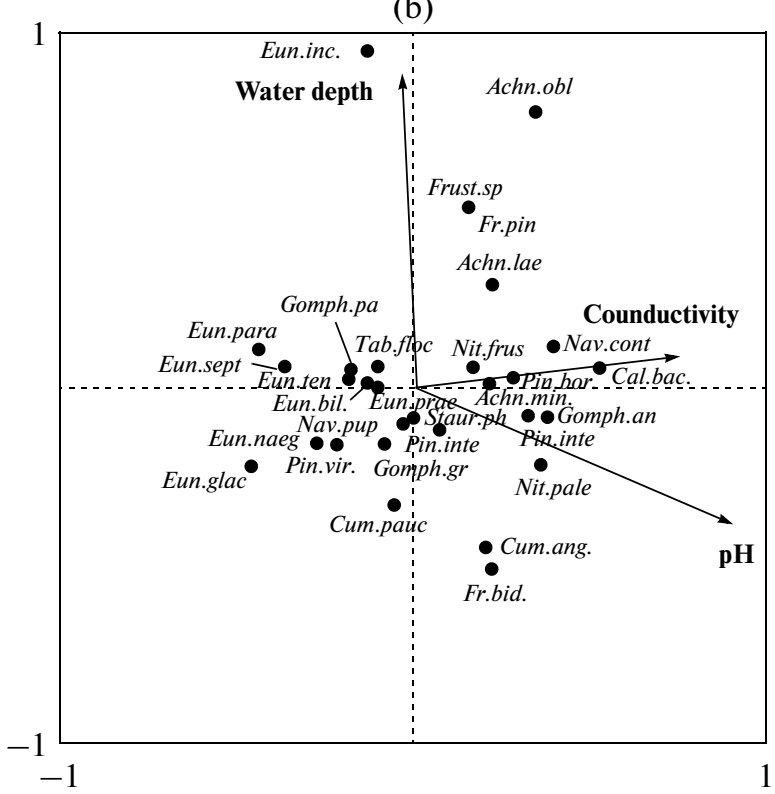

Fig. 4. A CCA diagram illustrating (a) relationship of the most significant environmental factors and diatom communities in the studied lakes and (b) individual diatom species in the studied lakes (subregions abbreviations as in Fig. 3). 
factors. The first of these includes species that exist in shallow waters of high latitudes with a neutral or weakly alkaline reaction of water with relatively high values of conductivity, such as Navicula contenta, Nitzschia paleacea, Caloneis baccilum, Achnanthes minutissima, and Cymbella angustata. The other set combines species adapted to survive in waters with relatively lower values of conductivity and neutral or slightly acidic environments located at lower latitudes at higher air temperatures. This includes species of the genus Eunotia [E. septentrionalis, E. praerupta, E. tenella] as well as Gomphonema parvulum and Tabellariaflocculosa. The identified diatom complexes can be used as indicators for monitoring climate change in Arctic regions.

\section{ACKNOWLEDGMENTS}

The authors express their deep gratitude to the operator of am Ultra 55 Plus Zeiss scanning electron microscope of the electron microscopy laboratory of the German Research Center of Geological Sciences in Potsdam Juliane Herwig for assistance in the electron microscopy of diatoms, as well as to Antje Eulenburg, the chemist at the Alfred Wegener Institute of Polar and Marine Research in Potsdam, for providing data on physicochemical studies of lakes of North Yakutiya.

The project was supported by the German Academy Exchange Service ("Mikhail Lomonosov" program, A0972849), Germany.

\section{REFERENCES}

1. Smol, J.P., Wolfe, A., Birks, H.J.B., Douglas, M.S.V., Jones, V.J., Korhola, A., Pienitz, R., Rühland, K., Sorvari, S., Antoniades, D., et al., Climate-Driven Regime Shifts in the Biological Communities of Arctic Lakes, Proc. Natl. Acad. Sci., 2005, p. 102, no. 3, pp. 43974402.

2. Battarbee, R.W., The Importance of Palaeolimnology To Lake Restoration, Hydrobiology, 1999, vols. 395396, pp. 149-159.

3. Davydova, N.N., Diatomovye vodorosli - indikatory prirodnykh uslovii vodoemov $v$ golotsene (Diatoms as Indicators of Natural Conditions of Water Bodies in Holocene), Leningrad: Nauka, 1985.

4. Alabyshev, V.V., Lake Sediments Zoning, Izv. Sapropelevogo Komiteta, 1932, no. 6, pp. 1-45.

5. Kiselev, I.A., Phytoplankton of Lakes of the Central Yakutiya by Materials of a Limnological Survey in 1932. Study of USSR Lakes, Tr. Gos. Gidrologich. Inst., 1935, no. 8, pp. 51-84.

6. Komarenko, L.E., A Description of Algal Flora and Zooplankton of the Middle Lena River Basin Water Bodies, Tr. Inst. Biologii YaF SO AN SSSR, 1956, no. 2, pp. 145-212.

7. Komarenko, L.E., Diatoms of the Kolyma River, Izv. Sib. Otd. Akad. Nauk SSSR, 1960, no. 3, pp. 81-90.
8. Komarenko, L.E., Plankton of left tributaries of the Vilyui River, Rivers Markha and Tyung, Tr. In-Ta Biologii YaF SO AN SSSR, 1962, no. 8, pp. 136-163.

9. Komarenko, L.E., A Composition and Forming of the Algal Flora of Water Bodies of the Yakutiya, in Pochvennye I Botanicheskie Issledovaniya V Yakutii, (Soil and Botanical Studies in the Yakutiya), Yakutsk, 1972, pp. 130-135.

10. Komarenko, L.E. and Vasil'eva, I.I., A Composition and Dynamics of the Algal Flora of Lakes of the Kolyma-Indidirka Lowland in the Open Water Period in 1966-1967, in Rybokhozyaistvennoe Osvoenie Ozer Basseina Srednei Kolymy, (A Fish Industry in Lakes of the Middle Kolyma Basin), Yakutsk, 1972, pp. 39-86.

11. Vasil'eva, I.I., Presnovodnye evglenovye i zhelto-zelenye vodorosli vodoemov Yakutii (Freshwater Euglenophytes and Yellow-Green Algae of Water Bodies of the Yakutiya), Leningrad: Nauka, 1987.

12. Vasil'eva I.I. Algae of Water Bodies in a Cryolite Zone of USSR: Systematics, Ecology, and Distribution (by Example of the Yakutiya), Extended Abstract of Doctoral (Biol.) Dissertation, Kishinev, 1989, p. 50.

13. Vasil'eva, I.I. and Ivanova, A.P., Algological Studies of the Saisara Lake, in Botanicheskie Issledovaniya V Kriolitozone, (Botanical Studies of a Cryolite Zone), Yakutsk, 1992, pp. 29-37.

14. Vasil'eva, I.I. and Ivanova, A.P., Diatoms of Lakes of the Tuimaada Lowland, in Ekologiya i geografiya diatomovykh vodoroslei: tez.dokl. VI Mezhdunar. shkoly po diatomovym vodoroslyam (Proc. VI Int. Meet. on Diatoms: Ecol. and Geog. of Diatoms), Minsk, 1995, pp. $11-13$.

15. Vasil'eva-Kralina, I.I. and Gabyshev, V.A., On Bacillariophyta of Mountain Water Bodies of the Verkhoyan'e (Yakutiya), Algologiya, 1996, vol. 6, no. 4, pp. 394-400.

16. Vasil'eva-Kralina, I.I., Rozhkov, O.F., and Rozhkova, O.Yu., Features of Seasonal Dynamics of Phyto- and Bacterioplankton of Streams in the "Olemkinsk” Natural Reserve(Sakha Republic, Yakutiya), Algologiya, 1996, vol. 7, no. 2, pp. 166-169.

17. Vasil'eva-Kralina, I.I., Ivanova, A.P., and Pshennikova, E.V., A Composition and Dynamics of Algae of Lakes of Yakutsk and its Vicinity (Middle Reaches of the Lena River), Algologiya, 1997, vol. 7, no. 1, pp. 30-34.

18. Pestryakova, L.A., Diatoms of Upper Horizons of Bottom Sediments of the Ulakhan Chabydy Lake, in Diatomovye vodorosli - indikatory izmenenii okruzhayushchei sredy i klimata: sb. st. Mezhdunar. diatom. shkoly (Proc. Int. Diatom Meet.: Diatoms as Indic. of Changes in the Inv. and Clim.), Irkutsk, 1993, pp. 5960.

19. Pestryakova L.A. Evolution of Lake Ecosystems of the Central Yakutiya (by Results of Diatom Analysis), Extended Abstract of Cand. Sci. (Biol.) Dissertation, Yakutsk: Izd-vo YaGU, 1994. p. 23.

20. Pestryakova, L.A., Diatoms of Bottom Sediments of the Nuochakha Lake (Middle Lena Basin), in Nauka I Obrazovanie, (Science and Education), 1998, vol. 4, pp. 63-65. 
21. Pestryakova, L.A., Bacillariophyta of Lake Sediments of the Central Yakutiya, Algologiya, 1999, vol. 9, no. 2, pp. 112-113.

22. Pestryakova, L.A., Diatom Complexes of Holocene Bottom Sediments of the Yakutiya. Lakes of Cold regions, in Voprosy Paleoklimatologii, Paleolimnologii I Paleoekologii, (Problems of Paleoclimatology, Paleolimnology, and Paleoecology), Yakutsk: Izd-Vo YaGU, 2000, vol. 4, pp. 151-160.

23. Pestryakova, L.A., Diatomovye vodorosli v osadkakh ozer Verkhnei Taty. Alasnye ekosistemy: Struktura, formirovanie, dinamika (Diatoms in Sediments of Lakes of the Verkhnyaya Tata. Alas's Ecosystems: Structure, Forming, and Dynamics), Novosibirsk: Nauka, 2005.

24. Pestryakova, L.A., Bosikov, N.P., and Ksenofontova, M.I., Diatom Complexes and Water Chemistry of Thermokarst Lakes of the Yukechinskogo firing ground, in Nauka I Obrazovanie, (Science and Education) 2007, vol. 2, pp. 19-24.

25. Pestryakova, L.A., Diatomovye Kompleksy Ozer Yakutii, (Diatom Complexes of Yakutiya's Lakes), Yakutsk: Izdvo YaGU, 2008.

26. Rapoport, L.G. and Romanovskii, N.N., Paleogeography of the Quaternary at the North Coast of the YanaIndigirka Lowland by the Diatom Flora, Voprosy Fizicheskoi Geografii Polyarnykh Stran, (Problems of Physiography of Polar Countries), 1959, vol. 2, pp. 196203.

27. Pirumova L.G. Diatoms of the Quaternary of the North Yana-Indigirka Lowland and the Bol'shoi Lyakhovskii Island, Iskopaemye diatomovye vodorosli SSSR (Fossil Diatoms of USSR), Moscow: Nauka, 1968, pp. 80-83.

28. Andreev, A.A., Grosse, G., Schirrmeister, L., Kuznetsova, T.V., Kuzmina, S.A., Bobrov, A.A., Tarasov, P.E., Novenko, E.Y., Meyer, H., Derevyagin, A.Y., Kienast, F., Bryantseva, A., and Kunitsky, V.V., Weichselian and Holocene Palaeoenvironmental History of the Bolshoy Lyakhovsky Island, New Siberian Archipelago, Arctic Siberia, Boreas, 2009, vol. 38, pp. 72110 .

29. Anisimov, M.A., Ivanova, V.V., Pushina, Z.V., and Pitul'ko, V.V., Lagoonal Deposits of the Zhokhova Island: Age, Forming Conditions, and Value for Paleoreconstructions of the Novosibirsk Islands Region, Izv. Akad. Nauk., Ser. Geograf., 2009, vol. 4, pp. 107-119.

30. Takhtadzhyan, A.L., Floristicheskie oblasti zemli (Floral Regions of the Earth), Leningrad: Nauka, 1978.

31. Gavrilova, M.K., Klimat Tsentral'Noi Yakutii, (Climate of the Central Yakutiya), Yakutsk: Institut Merzlotovedeniya AN SSSR, 1973.

32. Wetterich, S., Herzschuh, U., Meyer, H., Pestryakova, L., Plessen, B., Lopez, C.M.L., and Schirrmeister, L., Evaporation Effects As Reflected in Freshwaters and Ostracod Calcite from Modern Environments in Central and Northeast Yakutia (East Siberia, Russia), Hydrobiologia, 2008, vol. 614, pp. 171195.

33. Alekin, O.A., Osnovy gidrokhimii (Hydrochemistry Foundations), Leningrad: Gidrometeoizdat, 1970.
34. Battarbee, R.W., Diatom Analysis, in Handbook of Holocene Palaeoecology and Palaeohydrology, Berglund B.E., Ed., 1986, pp. 527-570.

35. Zabelina, M.M., Kiselev, I.A., ProshkinaLavrenko, A.I., and Sheshukova, V.S., Diatoms, in Opredelitel' presnovodnykh vodoroslei SSSR (Freshwater Diatoms of USSR Guide), Moscow: Sov. nauka, 1951, vol. 4.

36. Krammer, K. and Lange-Bertalot, H., Bacillariophyceae. 1. Teil: Naviculaceae, in Suesswasserflora Von Mitteleuropa, Stuttgart: Gustav Fischer Vg., 1986.

37. Krammer, K., Lange-Bertalot, H., Bacillariophyceae. 2. Teil: Bacillariaceae, Epitemiaceae, Surirellaceae, in Suesswasserflora Von Mitteleuropa, Stuttgart: Gustav Fischer Verlag, 1988.

38. Krammer, K. and Lange-Bertalot, H., Bacillariophyceae. 3. Teil: Centrales, Fragilariaceae, Eunotiaceae, in Suesswasserflora Von Mitteleuropa, Stuttgart: Gustav Fischer Verlag, 1991.

39. Krammer, K. and Lange-Bertalot, H., Bacillariophyceae. 4. Teil: Achnanthaceae, Kritische Erganzungen $\mathrm{Zu}$ Navicula (Lineolatae) Und Gomphonema. Geamtliteraturverzeichnis, in Suesswasserflora Von Mitteleuropa, Stuttgart: Gustav Fischer Verlag, 1991.

40. Aleshinskaya, Z.V. and Zaikina, N.G., Rukovodstvo $k$ prakticheskim zanyatiyam po kursu "Chetvertichnaya geologiya” (metod diatomovogo analiza) (Quaternary Geology: Workshop Manual, Diatom Analisis), Moscow: Izd-vo Mosk. Univ., 1964.

41. Barinova, S.S., Medvedeva, L.A., and Anisimova, O.V., Bioraznoobrazie Vodoroslei-Indikatorov Okruzhayushchei Sredy, (Diversity of Algal Indicators in the Environmental Assessment), Tel Aviv, 2006.

42. Sorensen, T., A New Method of Establishing Groups of Equel Amplitude in Plant Sociology Based on Similarity of a Species Content and Its Application To Analysis of Vegetation on Danish Common, Kgl. Dan. Selskab. Boil. Skr, 1948, vol. 5, no. 4, pp. 1-34.

43. Juggins, S., User Guide: C2, Software for Ecological and Palaeoecological Data Analysis and Visualization User Guide Version 1.3, in Department of Geography University of Newcastle, Newcastle upon Tyne, 2003, pp. 1-69.

44. Nazarova, L.B., Pestryakova, L.A., Ushnitskaya, L., and Hubberten, H.W., Chironomids (Diptera: Chironomidae) in Lakes of Central Yakutia and Their Indicative Potential for Paleoclimatic Research, Contemporary Problems of Ecology, 2008, no. 1, pp. 335345.

45. Birks H.J.B. Quantitative Palaeoenvironmental Reconstructions, in Statistical Modelling of Quaternary Science, Data., Technical Guide 5. Quaternary Research Association, Maddy, D. and Brew J.S., Eds., Cambridge, 1995, pp. 161-254.

46. ter Braak, C.J.F., Šmilauer, P., CANOCO Reference Manual and CanoDraw for Windows User'S Guide: Software for Canonical Community Ordination (Version 4.5), in Microcomputer Power., Ithaca, 2002. 